\title{
A Study on Monthly and Annual Average Temperature Variations in Mosul
}

\section{Basil Ibraheem Ahmad Ammar Mohammad Natheer Abdul Kadir Shakir Abdula \\ Technical Institute / Mosul}

\author{
Received \\ $10 / 07 / 2011$
}

\author{
Accepted \\ 06 / 06 / 2012
}

\section{خلاصة}

لوحظ في السنوات القليلة الأخيرة تغير واضح في مناخ الموصل قد يكون بسبب تأثير

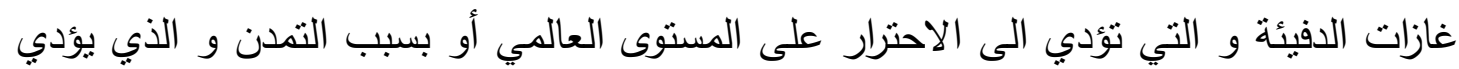


التحسس بالتغايرات المناخية. تحاول هذه الدراسة نوضيح هذه التغايرات الحاصلة في المعدل الثهري و المعدل السنوي لكل من درجات الحرارة العظمى و الصغرى خلال الفترة من 2005 2010. لغرض تأكيد البيانات المتاحة على درجات الحرارة العظمى و الصغرى أجريت مراجعة الهرات عملية لمدة 22 يوما خلال العام 2011. تم تحليل و مقارنة معدلات درجات الحرارة الصغرى و داليات العظمى (المتاحة) مع صافي نتائج 30 سنة للمعدلات الطبيعية بأستخدام طريقة الأنحار الخطي و ذلك للحصول على خطوط اتجاه لكل سنة من سني الدراسة. أظهرت الدراسة الحالية وجود تغيرات معنوية خارجة عن المألوف في المعدلات الشهرية لدرجة الحرارة خلال العام

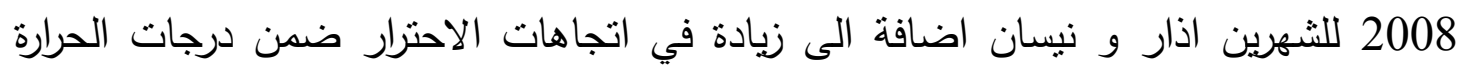

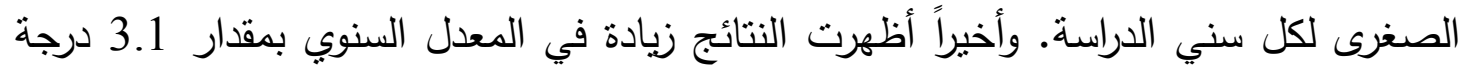
مئوية تقريبا للعام 2010 عن المعدل الطبيعي.

\begin{abstract}
In Mosul a climatic change was clearly observed in the last few years, this may be due to greenhouse gases effect which leads to global warming or urbanization which increases the regional minimum temperatures. As temperature plays a major role in detecting climatic changes, this work attempts to demonstrate the variations in monthly average and annual average for each of maximum and minimum temperatures during the period 2005-2010. Maximum and minimum temperatures were experimentally recorded for 22 days during 2011 to
\end{abstract}


confirm the available data. Maximum and minimum temperatures (available data) were analyzed and compared with net results of 30 years data by linear regression method to achieve trends for each year. The present study reveals a significant abnormal monthly temperature variations in March and April 2008, warming trends in monthly minimum temperature among most of years studied and an increase of approximately $3.1^{\circ} \mathrm{C}$ from normal average in the annual average temperature during 2010.

\section{Introduction:}

Climatic change has been an attractive issue for so many fields e.g. engineering, agriculture and urbanization. Numerous studies were carried out in the last 20 years. (Gadgil and Dhorde 2005(1) studied temporal variations in temperature over Pune city, India during the period 19012000 and showed significant decrease in annual average and annual average maximum temperatures which can be ascribed to a significant increase in the amount of suspended particulate matter (SPM) in the ambient air. To assess the effects of urbanization on local and regional climate Balling and Idso, 1989(2) Goodrich, 1992) (3) showed an increase in average temperature of $0.05^{\circ} \mathrm{C}$ per 100 years. A study in Japan by (Fujibe 1995) (4) showed a rising trend of $2-5^{\circ} \mathrm{C}$ per 100 years in minimum temperatures in several large cities in Japan. Another study on the variability of minimum and maximum temperature in Poland revealed that the strongest increase in maximum and minimum temperatures occurs in mid and late winter. However, beginning of winter and summer indicates decreasing tendencies. It is obvious now that changing land use and urbanization influence minimum temperatures. Due to the very high levels of energy consumption, large amount of waste heat is stored in building's walls and roofs which get released during the night, thereby making the night warmer (Wibig and Glowicki, 2002)(5). Assessing the impacts of urbanization and land use, a similar study by Thapliyal and Kulshreshtha (1991)(6) on temperature trends over Indian cities indicates a slight warming within the limits of $1^{\circ} \mathrm{C}$ standard deviation between 1901 - 1990. Chinese scientists have made studies on the effects of temperature change due to climatic changes (Lin and Yu, 1990 (7); Tang, 1996; (8) Ren et al., [2005](9). Most of them dealt with effects occurring in the past 50 years. Tang et al, 2010 (10) showed an annual mean temperature (averages of the whole country) increase by $0.78 \pm 0.27^{\circ} \mathrm{C}$ per 100 years in China for the period 1906-2005. After prolonging the period till 2007, it was found that 2007 was rated as the warmest year in the past 100 years.

Mosul city has been undergoing a variation in temperature effect. In order to reach a scenario on temperature trends in Mosul and because 
of the lack of the temperature affecting data (dust concentration, mean cloud amount, land use, etc...), the study attempts to focus on monthly and annual average temperature variations only. The city is located at latitude of $36.2^{\circ} \mathrm{N}$, longitude $43.2^{\circ} \mathrm{E}$, elevation rounding between $216-223$ $\mathrm{m}$ above sea level. The normal monthly average temperature (general average) characteristics are reported in table (1) as formulated from Funding Seismographic \& Meteorological Commission FSMC (Iraq) (11) for a period of 30 years beginning with the year 1978. It has been previously reported that the warmest year in Mosul was $1998\left(2.5^{\circ} \mathrm{C}\right.$ above normal), while $1972\left(1.8^{\circ} \mathrm{C}\right.$ below normal $)$ remains the coolest year (Climate Trends and Variations Bulletin - Annual 2009) (12).

Table (1): Normal monthly average and mean annual temperature in Mosul for 30 years.

\begin{tabular}{|l|c|c|c|}
\hline Month & $\begin{array}{l}\text { monthly average } \\
\text { maximum temperature }\end{array}$ & $\begin{array}{l}\text { monthly average } \\
\text { minimum temperature }{ }^{0} \mathrm{C}\end{array}$ & $\begin{array}{l}\text { monthly average } \\
\text { temperature }{ }^{0} \mathrm{C}\end{array}$ \\
\hline January & 12.4 & 2.2 & 7.3 \\
\hline February & 14.6 & 3.2 & 8.9 \\
\hline March & 18.8 & 6.4 & 12.6 \\
\hline April & 25.0 & 10.8 & 17.9 \\
\hline May & 32.7 & 16.0 & 24.35 \\
\hline June & 39.0 & 21.1 & 30.1 \\
\hline July & 43.0 & 24.9 & 34.0 \\
\hline August & 42.3 & 24.1 & 33.2 \\
\hline September & 38.2 & 18.8 & 28.5 \\
\hline October & 30.5 & 13.1 & 21.8 \\
\hline November & 20.9 & 7.1 & 14.0 \\
\hline December & 13.9 & 3.6 & 8.8 \\
\hline Mean annual temperature ${ }^{\circ} \mathrm{C}$ & 27.60833333 & 12.60833333 & 20.10833333 \\
\hline
\end{tabular}

\section{Data and Methodology:}

The daily maximum (Tdmax) and minimum (Tdmin) temperature data used in this work was extracted from Jeff Masters (13). The daily data sets of temperature were recorded experimentally in Mosul at a distance of about $500 \mathrm{~m}$ from the weathering station for an additional 22 days by using a simple weather station (Tech Line sensor by Schmid Electronics GmbH/ D-66780 Rehlingen - Siersburg) shown in figure (1). The outdoor wireless remote sensor (A) sends maximum and minimum temperature signal to the indoor weather meter (B). The part (A) was positioned in a well ventilated white wooden box $1.2 \mathrm{~m}$ high from ground and away from direct sun light (within the standard specification). 


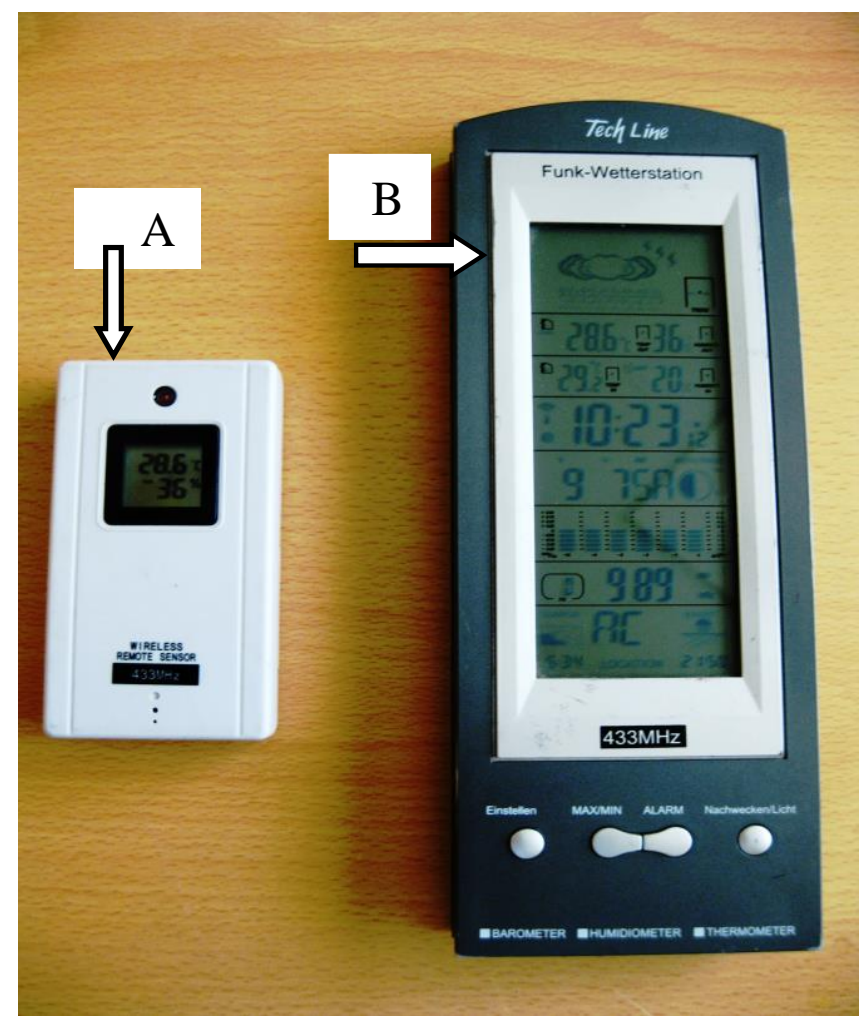

Figure (1): Simple weather station

Figure (2) demonstrates fair agreement of experimental and the online data as the experimental average maximum temperature for the readings was $28.09^{\circ} \mathrm{C}$ with standard deviation (SD) of $3.71{ }^{\circ} \mathrm{C}$, while the average maximum of online readings $(14)$ were $27.77^{\circ} \mathrm{C}\left(\mathbf{S D}=3.85^{\circ} \mathrm{C}\right)$. Similarly, in the case of minimum temperatures, the experimental average temperature was $16.32^{\circ} \mathrm{C}$ with SD of $2.47^{\circ} \mathrm{C}$ while the average of online temperature was $16.54^{\circ} \mathrm{C}\left(\mathbf{S D}=2.21^{\circ} \mathrm{C}\right)$. This small deviation can be due to the approximation (whole number) used by (14) and to apparatus positioning. These values were analyzed by using T-test which showed to be not statistically significant for maximum and minimum temperature recorded and online given (P-value ranged between 0.754 and 0.778 ).

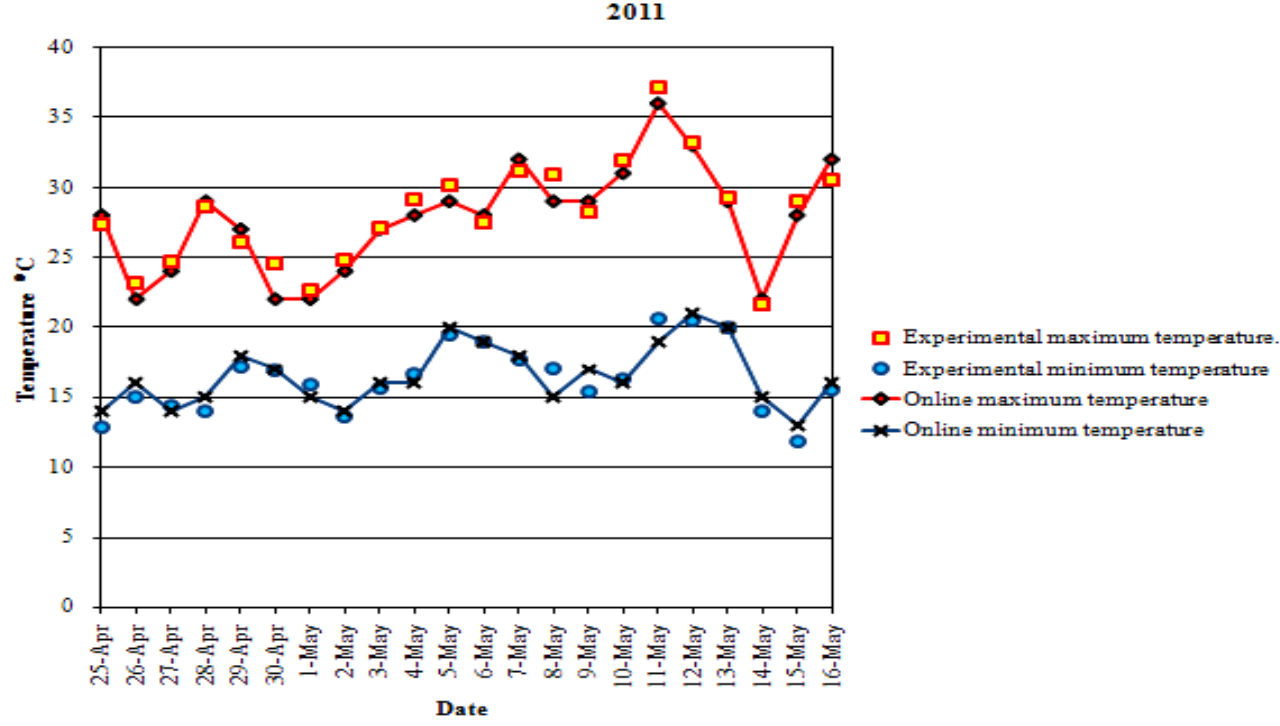

Figure (2): Comparison between temperatures online (12) extracted (the solid lines) and experimental temperature readings in April and May 2011. 
Maximum and minimum temperatures for 2212 days were analyzed using Excel tools for each specified month and year. Monthly average maximum temperature Tmmax was the mean value of all daily maximum temperatures in the specific month, in the same procedure monthly average minimum temperature Tmmin had been calculated. The mean value of Tmmax and Tmmin for the 12 months (year) gives the annual average maximum Tymax and annual average minimum temperatures Tymin respectively. Annual average temperature Ty is the mean of Tymax and Tymin. The thirty years historical data extracted from (11) was similarly formulated to find the normal (general) average of maximum Tmmax30 and minimum Tmmin30 temperatures. Tmmax30 and Tmmin30 were used to obtain a reference monthly temperature characteristic for comparison.

Monthly and annual average maximum, minimum temperatures trend lines (linear regression) with their equations and square of correlation coefficients $\left(\mathbf{R}^{2}\right)$ were chosen to observe the rate of changes and annual variations for each year and throughout the studied period. The year has warming trend if line slope with the intercept was higher than normal year slope and intercept.

\section{Results and Discussion:}

\section{Monthly average temperature trends:}

The normal average temperatures in table (1) are plotted in fig. (3) in order to show the maximum (Tmmax30) and minimum temperature (Tmmin30) normal trends throughout the thirty year period to be used as a reference for comparison. Figure (3) indicates that Tmmax30 trend line (linear regression) is $\mathrm{y}=0.887 \mathrm{x}+21.83$ with $\mathrm{R}^{2}=0.077$. On the other hand, Tmmin30 has a trend line of $\mathrm{y}=0.578 \mathrm{x}+8.87$ and $\mathrm{R}^{2}=0.063$.

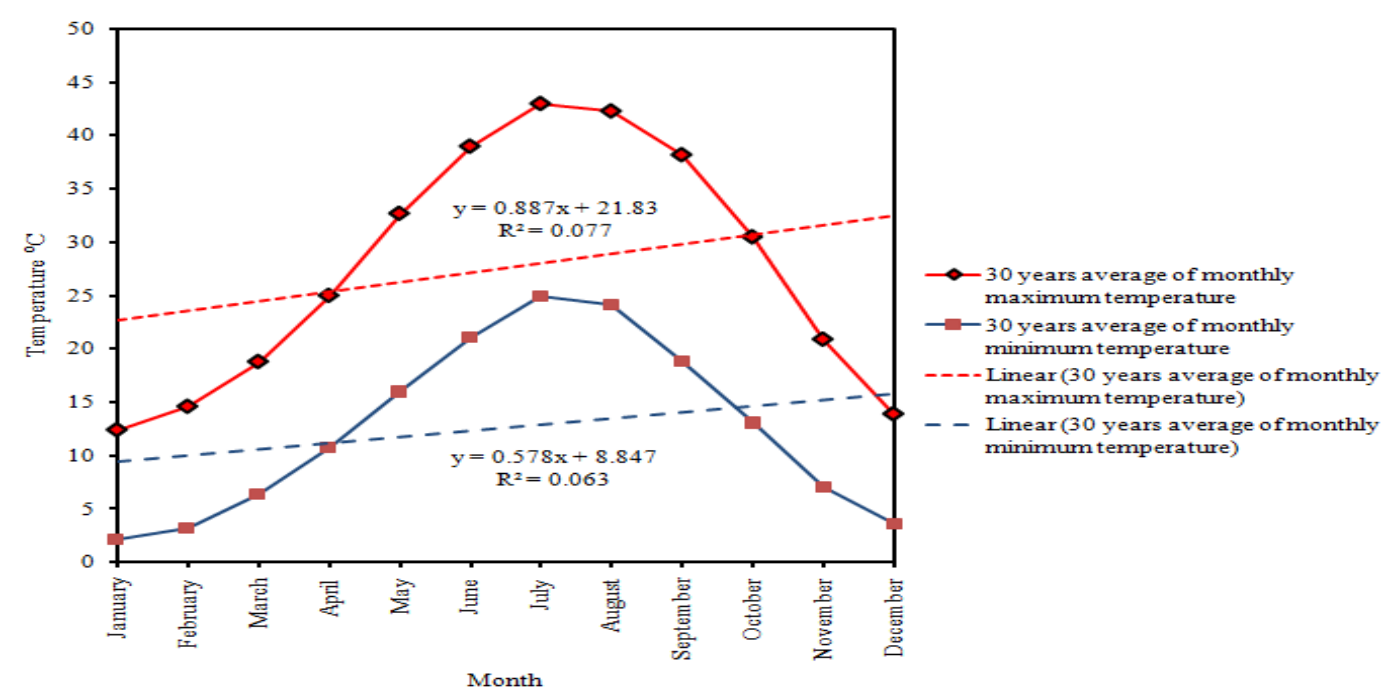

Figure (3): Normal variations in monthly average maximum and minimum temperature trends for 30 years. 
Figure (4) shows the monthly temperature characteristics for each year studied. In calendar year 2005 Tmmax trend line has the equation $y=0.972 x+21.79$ with $\left(R^{2}\right)$ of 0.098 , which begins cooler than Tmmax30 (by the intercept) but had warmer rate as line slope is higher. Similarly for Tmmin, the linear regression equation is $y=0.664 x+10.15$ and $\left(\mathrm{R}^{2}\right)=0.069$ which indicates warming in both intercept and slope.

Tmmax in the year 2006 demonstrated warmer start of $22.89^{\circ} \mathrm{C}$ in the trend line intercept and in spite of its lower slope than normal it was warmer. In July, 2006 there was a drop in $\mathbf{T m m a x}=41.67^{\circ} \mathrm{C}$ from the normal average $\left(43^{\circ} \mathrm{C}\right)$, while for $\mathbf{T m m i n}$ the trend line equation is $\mathrm{y}=0.367 \mathrm{x}+12.65$ and $\left(\mathrm{R}^{2}\right)=0.018$ with an increase due to the intercept $\left(12.65^{\circ} \mathrm{C}\right)$ although the slope is low as compared with Tmmin30. Both Tmmax and Tmmin exhibited similar behavior in trend lines in 2007.

On comparing fig. 3 and fig. 4 for the year 2008, there was a summer-like incidence in March and April for there has been an increase in Tmmax by $5.8,5.6^{\circ} \mathrm{C}$ and $\mathbf{T m m i n}$ by $4.2,5.66^{\circ} \mathrm{C}$ respectively. In January of the same year a drop in temperature was noted below the normal average by $1.37^{\circ} \mathrm{C}$ for $\mathbf{T m m a x}$ and $3.58^{\circ} \mathrm{C}$ in $\mathbf{T m m i n}$, still the year showed a slight cooling trend in Tmmax, however, obvious increase resumed in minimum temperatures throughout the year.

January 2009 also possess $1.2^{\circ} \mathrm{C}$ in $\mathbf{T m m i n}$ lower than $\mathbf{T m m i n 3 0}$ while all other months recorded higher temperatures than normal average by about $1-4^{\circ} \mathrm{C}$. Warming in minimum temperature was clear in the trend line equation $\left(y=0.748 x+10.45\right.$ with $\left.R^{2}=0.092\right)$. An overview of the low slope for Tmmax and its relatively high intercept $\left(23.04^{\circ} \mathrm{C}\right)$ indicates that the year was undergoing a cooling trend.

Heating trends were well noticed in the year 2010 especially for Tmmin where the intercept $13.53^{\circ} \mathrm{C}$ was greater than Tmmin30 by $4.68^{\circ} \mathrm{C}$. This was also true for Tmmax in the trend line slope (1.012) and the $23.21^{\circ} \mathrm{C}$ in intercept. 

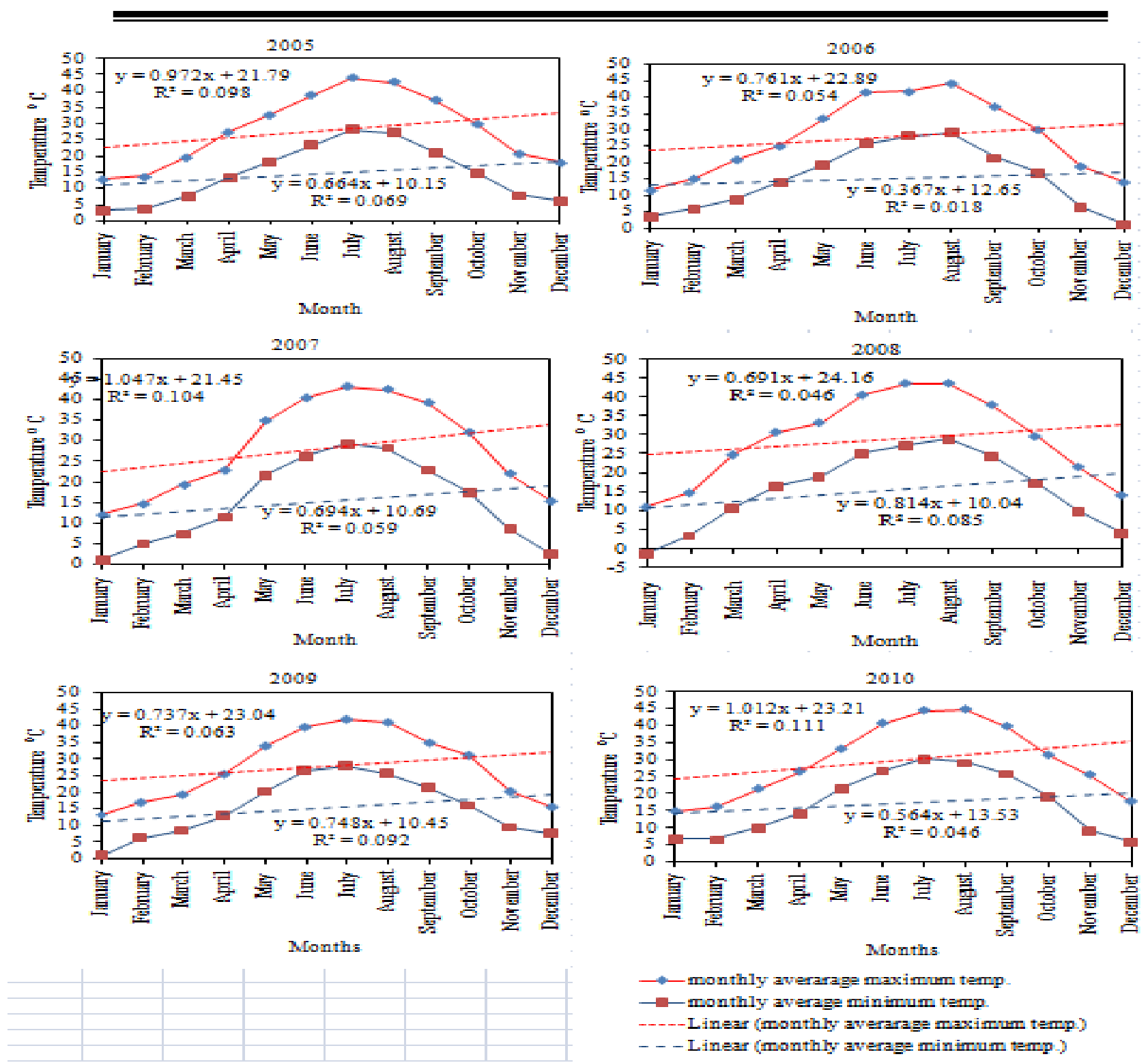

Figure (4): Monthly average maximum and minimum temperatures with their trends for Mosul in the period 2005-2010.

\section{Annual average temperature trends:}

Figure (4) shows the time series for monthly average maximum and minimum temperatures. Year by year warming is noted especially for Tmmin trend line with a slope of 0.51 which is higher than the slope of Tmmax, this indicates that minimum temperatures were the more effective parameters in the year warming. Figure (5) shows the variation in annual average maximum, annual average and the annual average minimum temperatures. It points to that $\mathbf{T y}$ had a maximum $\left(23.3^{\circ} \mathrm{C}\right)$ in the year 2010 and a relative drop in the year 2009 where $\mathbf{T y}=21.44^{\circ} \mathrm{C}$ and $21.26^{\circ} \mathrm{C}$ in the calendar year 2005 . Figure (4) and (5) also shows that in spite of the low Ty in 2005 the difference between Tymax and Tymin stays at a high level of $13.7^{\circ} \mathrm{C}$, and then fluctuates until it reaches a low value of $12.54^{\circ} \mathrm{C}$ for 2009 . 
A Study on Monthly and Annual Average Temperature Variations in Mosul.



Figure (5): Temperature trends for the studied years (2005-2010) in Mosul.

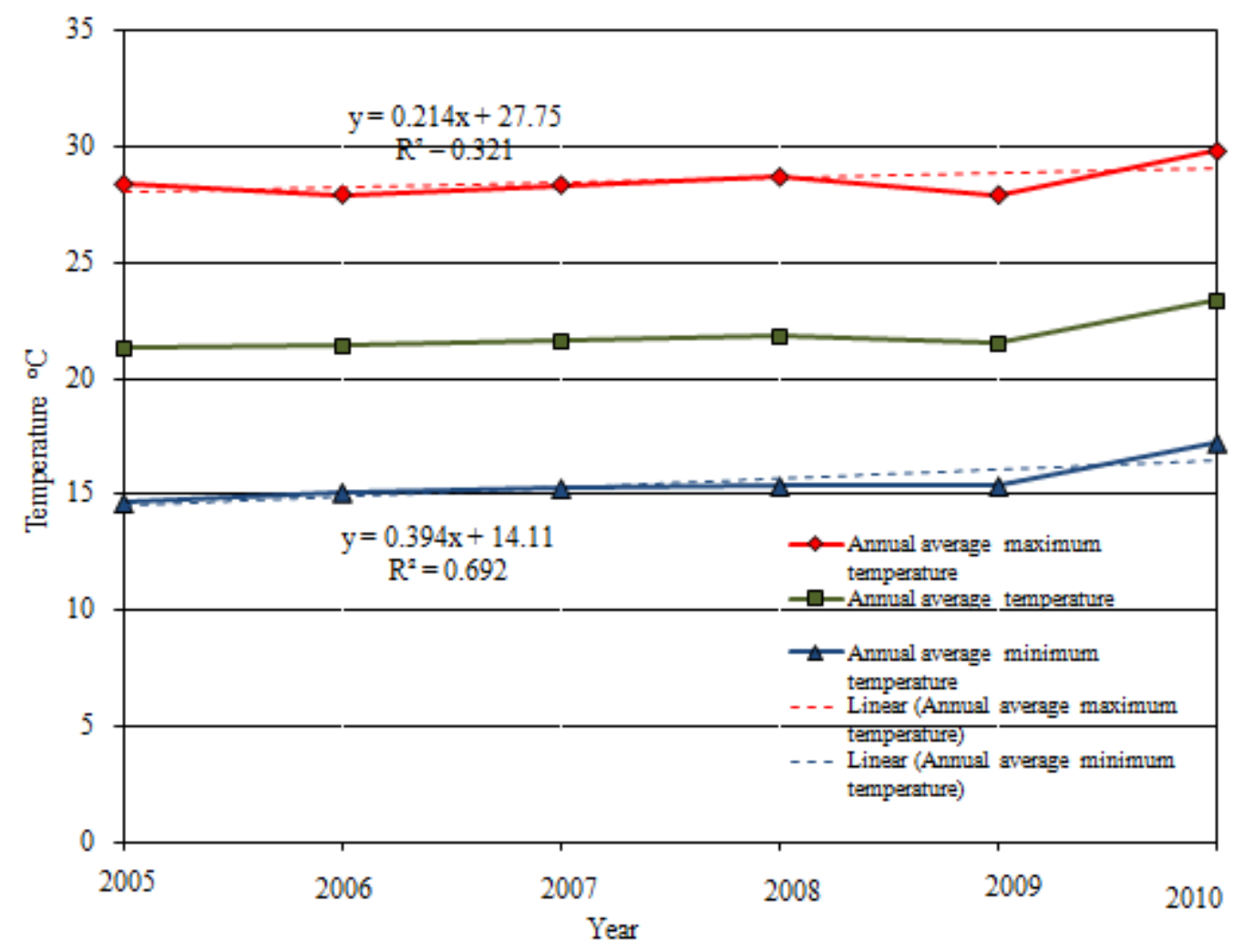

Figure (6): Variations in annual average maximum, annual average and annual average minimum temperatures in Mosul from 2005 to 2010. 
Acknowledgments:

The workers in the present study are thankful to the Funding Seismographic \& Meteorological Commission FSMC (Iraq) http://cosit.gov.iq/AAS2010/section_1/1-7.htm and to Jeff Masters for the online data sets in the website www.wunderground.com/blog/Jeff Masters/article.html

\section{References:}

1) Alaka, G., and Dhorde, A. 2005. Temperature trends in twentieth century at Pune, India. Atmospheric Environment 39 : 6550-6556.

2) Balling Jr., R.C., Idso, S., 1989. Historical temperature trends in the United States and the effect of urban population. Journal of Geophysical Research 94, 3359-3363.

3) Goodrich, J.D., 1992. Urban bias influences on long-term California air temperature trends. Atmospheric Environment. 26B, 1-7.

4) Fujibe, F., 1995. Temperature rising trends at Japanese cities during the last one hundred years and their relationships with population, population increasing rates and daily temperature ranges. Papers in Meteorologyand Geophysics 46: 35-55.

5) Wibig, J., Glowicki, B., 2002. Trends of minimum and maximum temperature in Poland. Climate Research. 20:123-133.

6) Thapliyal, V., Kulshreshtha, S.M., 1991. Climate changes and trends over India. Mausam. 42: 333-338.

7) Lin, X. and S. Yu, 1990: Climatic trend in China for the last 40 years. Meteorology. 16(10): 16-21.

8) Tang, G. 1996. Analysis of the trend of surface air temperature change over China. in: Climatic Change Rule and its Numerical Simulation Research, 1, Editorial Board for Papers in Project 85913 Topic 02, Eds., China Meteorological Press, 196-199.

9) Ren, G., M. Xu, Z. Chu. 2005. Changes of surface air temperature in China during 1951-2004. Climatic and Environmental Research. 10(4): 717-727.

10) Tang G., Yihui D., Shaowu W., Guoyu R., Hongbin L., Li Z. 2010. Comparative Analysis of China Surface Air Temperature Series for the Past 100 Years. Advances in Climatic Change Research. 1(1): 11-19.

11) Funding Seismographic \& Meteorological Commission FSMC (Iraq) http://cosit.gov.iq/AAS2010/section_1/1-7.htm

12) Climate Trends and Variations Bulletin - Annual 2009 http://www.worldclimate.com/cgibin/data.pl?ref=N36E043+1102+40608W

13) Online historical temperature data, Jeff Masters http://www.wunderground.com/history/airport/KQTU/2010/1/1/Cus tomHistory.html?dayend $=31 \&$ monthend $=12 \&$ yearend $=2010 \&$ req_c ity $=$ NA\&req_state $=$ NA\&req_statename $=$ NA

14) Online daily temperature data http://www.wunderground.com/cgibin/findweather/getForecast?query $=36.29999924,43.15000153$ 